\title{
Analysis on the Ownership of Urban Underground Utility Tunnel
}

\author{
Qian Jiuling $^{1}$, Cao Fuguo², Zhen Deyun ${ }^{3}$ \\ ${ }^{1}$ The School of Public Finance and Taxation, Central University of Finance and Economics, Beijing, P. R. China \\ ${ }^{2}$ The School of Law, Central University of Finance and Economics, Beijing, P. R. China \\ ${ }^{3}$ National Tax Institute of State Taxation Administration of China, Yangzhou, China
}

Email address:

qianjiuling@163.com (Qian Jiuling),cao_fuguo@aliyun.com (Cao Fuguo), zhdynk@126.com (Zhen Deyun)

\section{To cite this article:}

Qian Jiuling, Cao Fuguo, Zhen Deyun. Analysis on the Ownership of Urban Underground Utility Tunnel. Urban and Regional Planning. Vol. 4, No. 3, 2019, pp. 115-120. doi: 10.11648/j.urp.20190403.15

Received: September 9, 2019; Accepted: October 21, 2019; Published: October 23, 2019

\begin{abstract}
The utility tunnel contains important infrastructure such as electricity, communication and heating, which is related to the vital interests of the people. The utility tunnel construction can effectively solve the problem of "road zipper", make good use of underground space resources and improve the city's comprehensive management capabilities. Based on the observation of theory and practice, the problem of ownership of urban Underground utility tunnel is a prominent problem affecting its development. There is a lot of controversy over ownership issues, and most SPV (Special Purpose Vehicle) company want to enjoy it, which is good for bank financing. However, The utility tunnel has special characteristics, and the government enjoys the ownership can better protect the public interest. In most cases of the PPP project, it is based on such considerations that the ownership of the assets belongs to the state. For the better development of underground utility tunnel, it is urgent now that we need to improve the legal system of underground space and set standards for transfer of ownership. In order to facilitate the financing of SPV company, we should improve the the pledge of accounts receivable and the path of asset securitization, instead of relying solely on the traditional real estate mortgage to realize the function of guarantee.
\end{abstract}

Keywords: Utility Tunnel, Ownership, Criterion

\section{Introduction}

As an important urban infrastructure construction, the Underground utility tunnel has highlighted its economic and social benefits. Based on the observation of theory and practice, the problem of ownership of utility tunnel is a prominent problem affecting its development. Through the observation of cases, it is found that the ownership problem in the construction of the utility tunnel is quite controversial. The consideration factors for the transfer or not include financing and double taxation. While the experience of the development of utility tunnel is being studied, legislation should be adopted to clarify the ownership in order to establish criteria for transfer of ownership that allows ownership transfer to be applied to all PPP projects. On the issue of the ownership of the utility tunnel, the pledge of accounts receivable should be improved to achieve the guarantee function, to realize the need for financing and to avoid a series of problems caused by ownership transfer. Through the discussion on the ownership of urban underground utility tunnel, it is conducive to promoting the consensus of all stakeholders on urban utility tunnel development under the PPP model.

The issue of "the Ownership of Urban Underground Utility Tunnel" is a worthy topic for investigation. The paper is organized logically and structured clearly. The purpose and significance of the study is clearly stated. However, there are still many obvious problems in this paper. The proposed measures for ownership need to be further deepened, and the internationality needs to be improved.

\section{Opportunities and Challenges in the Construction of Utility Tunnel}

\subsection{Opportunities and Prospects of Utility Tunnel Development}

The development and utilization of underground space is a 
product of modern social development. The use of land by mankind is concentrated in agriculture, while there are few considerations about underground stratification. Since the industrial revolution in the 19th century, with the expansion of the city and the development of modern technology, the use of land has gradually developed in a three-dimensional manner. Land can be divided into three parts: surface, air and underground. With the change of ownership concept, underground space ownership doesn't only cover land ownership, but also gradually become independent with their own independent value [1]. After entering the 20th century, many countries have enacted laws related to the development of land space, and the development of urban underground space has gradually begun.

Urban underground utility tunnel refers to the public tunnel used for centralized laying of municipal pipelines such as ones for electricity, communication, radio and television, water supply, drainage, heat and gas [2]. The utility tunnel is one of the important signs of the modernization of the new city municipal management of infrastructure construction, and has a good effect on avoiding repeated excavation of modern urban roads [3]. The construction of the utility tunnel is a "100-year project", which is built to a high standard and comprehensively the needs in 100 years. It is a major project for the benefit of the country and the people [4]. At present, the speed of urbanization in China is accelerating, and the speed of infrastructure construction needs to be accelerated [5]. It is very necessary to attach importance to the construction and development of underground utility tunnel in urban planning. The State Council attaches great importance to the construction and development of utility tunnel, and regards the construction of utility tunnel as a nationally supported project for people's livelihood, which can increase the supply of public goods while meeting the needs of the people.

The construction of utility tunnel can effectively solve the problem of "road zipper", make best of underground space resources and improve the city's comprehensive management capabilities. The long-term benefits of urban underground utility tunnel construction are obvious. Although the underground utility tunnel has a long construction time and cost, it has a long service life after construction, and it reduces the cost of maintenance and can bring great social and environmental benefits. The cost of building a utility tunnel is high, which can also boost GDP growth to a certain extent. In 2015, the Ministry of Finance announced ten pilot cities for underground utility tunnel. Half of the pilot projects were rated as PPP demonstration projects of the Ministry of Finance, and the proportion of projects evaluated was very high. The state paid more and more attention to the construction of utility tunnel, and each pilot city had a large amount of financial subsidies.

Although the development of the underground utility tunnel has just started, it has a very broad development potential, which is conducive to the rapid development of the city and to the promotion of economic growth. The comprehensive utility tunnel marks the transformation of China's urban construction development mode. The economic benefits and social benefits of the utility tunnel are highlighted. From the perspective of the whole life cycle, it saves land space, reduces the phenomenon of repeated excavation and the impact of accidents on traffic. Incorporating all types of municipal pipelines into intensive public tunnels will result in huge infrastructure investments. The utility tunnel involves different industries such as engineering construction, building materials, machinery and equipment, which indirectly drives investment in steel, cement, machinery and equipment, as well as a large amount of manpower input, which will have a greater impetus to the economy. In 2015, a total of 69 cities in China launched a comprehensive underground pipeline construction project of about 1,000 kilometers, with a total investment of about 88 billion yuan. The construction of the utility tunnel will have far-reaching and positive impact on urban development, economic growth, and people's lives.

\subsection{Controversy Over the Ownership of the Utility Tunnel}

The utility tunnel will encounter many problems during the construction process, such as land, tenure, management, financing issues, operational issues and technical difficulties. The problem of land is originated from the imperfect provisions of the Real Right Law and the Land Law on the right to use construction land. The management issues are more about the issue of compulsory access. The utility tunnel is in the early stage of development, and the various systems need to be further improved. The consideration of the incorporation units is more directly related to their existing interests and neglecting long-term development. In addition, the long construction period and high cost of the utility tunnel are also difficult problems in practice. These problems must be properly solved, otherwise it will directly affect the long-term development of the utility tunnel. Whether the independent property right can be kept in the development of urban underground space, the Land Law does not clarify this issue. Although the Real Right Law stipulates the right to use underground construction land, the regulations are not refined and lack specific guide to practice. Who should own the ownership of the utility tunnel? What kind of rights does the SPV company have? What kind of rights does the utility tunnel have? These issues are not regulated by law.

Rule of law is an important way to optimize urban development. When the city develops to a certain stage, the environment of the rule of law is particularly important. The rule of law embodies the concept of state governance and creates conditions for the realization of modernization of state governance [6]. The rule of law is an important path for building modern cities. Infrastructure construction is closely related to urban development. The sound development of cities depends on the promotion of infrastructure construction. In the development of modern cities, there are many problems in infrastructure construction. The utility tunnel is representative of important infrastructure construction projects. Its ownership is directly related to the construction and operation of the project, and is related to the efficiency of the project operation, the management method and the sharing 
of risks. Through the study of relevant cases in practice, it is found that the dispute of ownership transfer is quite controversial, and the practices in different places is different. Some cases are based on the need for financing, and the transfer of ownership facilitates the mortgage of the SPV company. In other cases, ownership issue is handled more cautiously and does not transfer during the construction period. The issue of ownership is so sensitive that it has affected the operation of the project, as a result to clarify its ownership issues is conducive to reducing disputes in the construction of utility tunnel.

\section{Analysis of the Ownership of Utility Tunnel}

The ownership of utility tunnel is highly controversial in the construction of urban underground space, and the issue of ownership is a difficult problem encountered in the currentutility tunnel. Not only the utility tunnel, but also the disputes over ownership issues in other PPP projects are there. This paper takes the ownership problem of urban underground utility tunnel as the starting point and explores the issue of asset ownership.

According to the case published by the PPP Center of the Ministry of Finance, some PPP project contracts directly stipulate that the SPV company has ownership within a certain period of time, while there are agreements that the government has ownership with SPV company right to possess and benefit [7]. For example, in the utility tunnel project of Baotou City, the SPV company owns all the assets of the project (including the assets formed by the replacement reset or transformation).

The basis for transferring ownership is that some people think that it stipulates "who builds, who owns"in the Real Right Law and the land use right holder can enjoy the ownership of buildings, structures or ancillary facilities according to the construction behavior. In road sector to promote PPP, it is gradually open up in roads, railways, oil and gas pipelines, etc [8]. At present, the rare practice in PPP projects is that the SPV company obtains ownership within the agreed time limit. After the agreed time limit, the ownership is transferred to the government. The SPV company with ownership is conducive to the investment and financing. Because the construction of utility tunnel requires a large amount of funds, many banks restrict the loan for a prerequisite that SPV companies need to obtain ownership before they can release loans. Therefore, this method is conducive to the construction of utility tunnel, which is conducive to financing and solving the funding gap. Ownership of the SPV company and the ownership of the infrastructure sector are gradually liberalized. It can be agreed between the parties that the SPV company obtains ownership, which facilitates the establishment of security interest by the financial institution and SPV company's financing. As for the financial institution's request for the guarantee provided by the SPV company, since the SPV company is a newly established company, placing the ownership in the name of the SPV company can solve the problem of financing difficulties.

The other method is that the SPV company has only obligation to build and operate project, and has the right to collect income. The SPV company can pledge the income to realize the financing needs. After the analysis of the public demonstration cases published by the Ministry of Finance, it is found that ownership of most of theutility tunnel projects weren't transfered to the SPV company, but agreed to ownership by the government.

Based on the investigation of the ownership of the utility tunnel project, the government and the SPV company agreed that the ownership does not shift because of the nature of theutility tunnel. Article 52 of the Real Right Law is about the state ownership of national defense assets and the of the state-owned infrastructure. The first paragraph determines that the national defense assets belong to the state, and the national defense is the guarantee for the survival of the country. Therefore, it is determined that the national defense assets belong to the state which is in the interest of the security of the national defense assets. Paragraph 2 establishes infrastructure such as railways, highways, electrical facilities, telecommunications facilities and oil and gas pipelines, which are owned by the State in accordance with the law. But not all infrastructure is owned by the state except owned by the state in accordance with the law.

In addition to the provisions on the ownership of infrastructure in the Real Right Law, there are also reasons for double taxation. If the ownership of the SPV company is transferred during the construction period, it will be transferred to the government at the time of expiration, and each transfer will face a large amount of tax revenue. It is based on such considerations that in the construction project of the utility tunnel, the ownership is not transferred. The SPV company has only the right to construct and operate, and does not enjoy ownership during the construction period.

\section{Recommendations on the Ownership of the Utility Tunnel}

\subsection{Legal Analysis of Ownership Issues}

Article 142 of the Real Right Law stipulates the ownership of buildings and other facilities built by the land use right holders. The ownership of buildings, structures and their ancillary facilities constructed by the owner of the construction land shall be owned by the owner of the construction land, except where there is evidence to the contrary. In countries that pursue private ownership of land, ownership is generally determined by the principle that land rights absorb land rights. However, China's situation is unique. China does not allow land to be private, and the ownership of buildings, structures and their ancillary facilities is relatively independent. Ownership and use rights may belong to different entities. After the construction land use right holder obtains the right to use state-owned land according to law, it has the right to use the land to construct buildings, structures and their ancillary facilities. 
Article 30 of the Real Right Law stipulates that if a house is legally built, the ownership of the building is obtained from the factual act. In most cases, the ownership of buildings, structures, and ancillary facilities built by the owner of the construction land belongs to the owner of the construction land. This is the general principle of ownership. However, there are exceptions to this situation. In modern real estate construction, some municipal public facilities are built by developers, but ownership belongs to the state because this part of the infrastructure belongs to the municipal public, the vesting is in accordance with the prior agreement, and not of course belongs to the construction land use right holder.

Article 52, paragraph 2, of the Real Right Law establishes infrastructure such as railways, highways, electric power facilities, telecommunication facilities and oil and gas pipelines, which are owned by the state in accordance with the law and are owned by the state. But not all infrastructure is owned by the state except owned by the state in accordance with the law, and it belongs to the state. There are currently no relevant regulations on the ownership ofutility tunnel assets. However, we understand from the essence of Article 52 of the Real Right Law that the infrastructure clearly defined by the law is state-owned and ownership belongs to the state. These facilities are related to the economic development of the country and the safety of people's lives and property. It is stipulated that the state can improve the speed of construction of infrastructure, the efficiency of use and the security of infrastructure. For example, Article 4 of the Electricity Law stipulates that any unit or individual is prohibited from harming the safety of electric power facilities or illegally occupying or using electric energy. The same is true for telecommunications services. The utility tunnel contains municipal lines such as electricity, communications, radio and television, water supply, drainage, heat, gas, etc., so it is not feasible to obtain the ownership of the utility tunnel according to the factual construction act.

The reason why SPV company wants to own real estate ownership is that if there is no ownership, the SPV company will face an embarrassing situation of only investing and no assets. However, few people want to purchase the ownership of the utility tunnel. According to the PPP contract, once the government cancels the contract, the assets can be directly collected. Even if the SPV company enjoys the ownership of the assets, it cannot be mortgaged or be disposed of. The scope of the guarantee law also excludes the public welfare infrastructure from the scope of the guarantee. Even if the SPV company has ownership, it cannot be mortgaged, and it will face the problem of taxation. This will actually affect the enthusiasm of social capital to participate in the construction of theutility tunnel project. Therefore, the ownership of real estate by the SPV company has lost its practical significance.

It can be argued that ownership of the SPV company of the utility tunnel is not appropriate, both in terms of legal provisions and from the jurisprudence and practice. The utility tunnel is the type of project developed in recent years. It understands in the essence of Article 52 of the Real Right Law that the reason why the law stipulates that the infrastructure belongs to the state is to ensure that the public interest is not infringed. The utility tunnel contains electricity, communication, etc. infrastructures. The important infrastructure is closely related to the vital interests of the people. In most cases of the utility tunnel project, it is also based on such considerations that the ownership of the assets belongs to the state.

\subsection{Criteria of Ownership Transfer}

In the construction of PPP projects, ownership is directly related to the important issues of project construction. Utility tunnel are an independent industry in the infrastructure sector, and the transfer of ownership requires the identification of relevant standards. With the development of the economy, many industries that were originally controlled by the state are slowly opening up market access conditions and fully introducing competition. However, the liberalization of market access conditions does not mean the transfer of ownership, but whether it is transferred or not depends on the actual situation. At present, in the field of utility tunnel, the importance of utility tunnel is self-evident because the corridor contain power, telecommunications and heating pipes. Through the legal and economic analysis of the utility tunnel, it is more appropriate not to transfer ownership in the construction of the utility tunnel.

The utility tunnel is just one of these industries, in addition to many other industries, such as garbage disposal, water conservancy construction, sponge city and so on. According to the nature of the industry, or from the overall perspective of ownership, the standard of ownership transfer can be formulated as early as possible, which can solve the problem of ownership of theutility tunnel, and can also provide reference for ownership issues in all projects.

A PPP contract is an incomplete contract [9]. Based on the particularity of an incomplete contract, all situations cannot be included. As a result, ownership issues become more important, and owners who have "remaining control" can process assets [10]. Ownership should be given to the party who is more concerned with the project's "remaining control" [11]. In the PPP project, because of the particularity of the public interest and it is more important that the PPP contract is an incomplete contract, ownership by the government contributes to the realization of the public interest.

\subsection{Improvement of Pledge of Accounts Receivable and Asset Securitization}

The transfer of ownership is based on the need for financing. The existence of ownership is conducive to the establishment of security interest. If the SPV company does not enjoy ownership, the most unfavorable thing is that the right holder cannot obtain the security right when financing. Legally, accounts receivable is a kind of creditor's right [12], and the pledge of receivables is a kind of pledge of rights. Although the pledge of accounts receivable can also play the role of guarantee, but financial institutions prefer mortgages. The realization of the interests of financial institutions can be 
protected by improving the income of accounts receivable.

The SPV company cannot use the utility tunnel for mortgage financing, but it can take a different approach. The construction of the utility tunnel requires a lot of money. The cost of underground construction may be greater than that required for construction on the ground. The SPV company may consider pledge of its income right to achieve the purpose of financing.

According to the statutory principle of property rights, and with reference to the No. 53 of the 11th batch of guidance cases published by the Supreme Court. The franchise right owned by the SPV company shall be one of the creditor's rights, the franchise right may be pledged, and the pledge registration may be carried out as accounts receivable. Where the right to benefit from the franchise shall not be discounted, auctioned or sold according to its nature, if the pledgee advocates preferential compensation, the court may order the debtor of the pledge to give priority to the pledgee of the income receivable. The franchise of the SPV company is the right to operate, maintain and obtain the corresponding income for the infrastructure, in which the operation and maintenance are obligations, and the income right is the right. Therefore, the core of the franchise is the right to income, which belongs to the future monetary claims. According to its nature, it can be included in the scope of "accounts receivable" that can be pledged according to law. According to the provisions of Article 97 of the Judicial Interpretation of the Guarantee Law, if the right to the real estate income such as highways and bridges is pledged, it falls within the scope of the pledge of the rights of the security law.

The pledge of the receivables can also play a role of guarantee to a certain extent, although it cannot be compared with the guarantee function of real estate mortgage, In addition, asset-based securitization of accounts receivable can be considered [13]. Asset securitization is based on a specific asset portfolio or cash, and tradable securities are issued to realize the liquidity of funds. When the underlying assets support securitization, the assets must be specific, independent, and have a predictable and stable cash flow. The function of guarantee through the pledge of rights not only satisfies the needs of financing, but also provides funds for project construction. By improving the pledge of accounts receivable and the path of asset securitization, instead of relying solely on the traditional real estate mortgage to realize the function of guarantee, the financing method is improved.

\subsection{Improvement of Legal System for Underground Space Construction}

There are many problems encountered in the utility tunnel one of which is its ownership. The existing normative basis is very limited, which directly causes the dilemma in practice. For the construction of infrastructure such as utility tunnels, legislation needs to be clarified, so that the government can make specific plans according to actual conditions [14]. With analysis of the successful development experience of pilot cities, it is without exception that government needs to rationally arrange urban development planning and corridor planning where government plans and coordinates the relationship between various departments before construction, formulates regulations for the construction of utility tunnels, and creates a good institutional environment for the development of utility tunnels. In the demonstration projects such as Harbin, Liupanshui and Baotou City, all the urban master plans will be made first, and the underground space utilization plan will be compiled under the overall urban planning [15]. It focuses on the content of the construction of utility tunnels, and promotes the construction of utility tunnels as the focus of urban development. These cities are very focused on the formulation of regulations, and various localities have formulated management measures related to the construction of utility tunnels. The construction planning, operation management, payment methods, etc. of the utility tunnel are clearly defined in the form of regulations.

In addition, there are few provisions on the construction of underground space in the Real Right Law, and the provisions on the right to use underground construction land are more vague in Article 136. The construction of underground space will gradually expand with the development of the city, for example, underground civil air defense projects, underground garages in the community, etc. More problems will arise in the corresponding practice. It is hoped that the in Real Right Law can be provided corresponding provisions on the construction of underground space, including ownership issues and registration issues.

\section{Conclusion}

The utility tunnel is one of the important signs of the modernization of the new city's municipal management infrastructure. Based on the observation of theory and practice, the problem of ownership of urban underground utility tunnels is a prominent problem affecting its development.

As a municipal infrastructure, the utility tunnel is owned by the state. The problem that legislation needs to solve is to establish the right to use underground space and the ownership of underground works. The existing right to use underground space for construction has been recognized by the law, but the relevant supporting facilities are not regulated in the legal documents. There is no relevant law to stipulate this. The construction, operation and maintenance of the utility tunnel requires laws or regulations at the national level, and there are still many imperfections in the current legal regulations. We should formulate laws or regulations based on our own actual situation, drawing on the experience of developing countries in this aspect.

The utility tunnel contains important infrastructure such as electricity, communication and heating, which is related to the vital interests of the people. Therefore, the ownership of the utility tunnel should belong to the state. The ownership of the utility tunnel is unique. The utility tunnel is part of the infrastructure construction and involves many public interests. According to the provisions of the Real Right Law, the infrastructure should be within the scope of the state-owned property. The ownership of the utility tunnel by the SPV 
company is contrary to the provisions of the current Property Law. The guarantee law excludes the construction of public welfare infrastructure from the scope of the guarantee. As a result there is no need to transfer ownership.

But it does not mean that the ownership of all projects can not be transferred. It requires to distinguish the situation. According to the nature of the land and related industries, it determines whether the ownership of the assets can be transferred. To the extent permitted, the SPV company can enjoy ownership of the project assets. The current PPP projects are in full swing. The issue of asset ownership needs further research, and specific criteria need to be further studied.

\section{References}

[1] Ma Yusheng: On the Construction of Urban Underground Space Right and Its Property Law [J], Journal of Legal Business, 2010 (3)

[2] Guiding Opinions of the General Office of the State Council on Promoting the Construction of Urban Underground utility tunnel. ([2015] No. 61).

[3] Qingxia, Chen. Dynamic response of utility tunnel during the passage of Rayleigh waves [J]. Earthquake Science, 2010, 23 (1).

[4] "Technical Specifications for Urban utility tunnel" (GB50838-2015).

[5] Ju Di, Research on Risk Distribution of PPP Projects under Incomplete Contract Theory- Taking PPP Project of G City Underground utility tunnel as an Example, Management Observatory 2019, (24).
[6] Dicey A V. The Law of the Constitution [J]. Journal of Political Economy, 2012.

[7] Mao Huixian, Research on the operation and management mode of urban underground utility tunnel_- Taking the pilot project of underground comprehensive pipe gallery in Suzhou as an example, reform and opening up, 2019 (10).

[8] PPP project construction international seminar series three seminars: PPP project asset ownership legal issues [J], Chinese government procurement, 2016 (3).

[9] Benjamin Klein, Transaction Cost Determinants of "Unfair" Contractual Arrangements [J], The American Economic Review, Vol. 70, No. 2, 1980.

[10] Oliver Hart: incomplete contracts and public ownership: remark, and an application to public-private partnerships [J], The Economic Journal, 2003, 113 (March).

[11] Besley, T. and Ghatak, M. Government versus private ownership of public goods [J], Quarterly Journal of Economics, 2001, $116(4)$.

[12] Jia Kang, Research on Investment Return Mechanism of Urban Underground utility tunnel, Economic Research Reference, $2018(21)$

[13] LI Yan-li, Beijing Sport University. Research on Asset Securitization for Large Sport Facilities in China under the Marketization Reform [J]. China Sport Science \& Technology, 2014.

[14] Xing Hongfei, on several issues of urban underground space rights, Nanjing Social Science, 2011 (8).

[15] $\mathrm{Hu}$ Zhengfang, on the legal issues of the construction of underground space rights in China, politics and law. 2006 (5). 